\title{
HUBUNGAN PENDAPATAN KELUARGA, BERAT LAHIR, DAN PANJANG LAHIR DENGAN KEJADIAN STUNTING BALITA 24-59 BULAN DI BANGKALAN
}

\author{
Rizki Kurnia Illahi* \\ *Departemen Gizi Kesehatan, Fakultas Kesehatan Masyarakat \\ Universitas Airlangga, Surabaya \\ Email: rizki.kurnia-12@fkm.unair.ac.id
}

\begin{abstract}
ABSTRAK
Stunting masih menjadi permasalahan gizi di Indonesia. Prevalensi stunting balita tahun 2015 di Kabupaten Bangkalan paling tinggi di Jawa Timur. Banyak faktor yang menyebabkan kejadian stunting balita. Salah satu faktor yang mempengaruhi di antaranya karakteristik keluarga dan karakteristik balita. Tujuan penelitian ini adalah untuk menganalisis hubungan pendapatan keluarga, berat lahir, dan panjang lahir balita dengan kejadian stunting balita.

Penelitian ini merupakan penelitian observasional dengan rancang bangun cross sectional. Populasi sebanyak 73 balita. Besar sampel 62 balita yang dipilih dengan metode simple random sampling. Kriteria sampel yaitu: balita berasal dari keluarga penduduk tetap, tidak mengalami cacat fisik dan gangguan mental. Variabel penelitian adalah pendidikan ibu, status pekerjaan ibu, pendapatan keluarga, jumlah anggota keluarga, umur balita, berat lahir, panjang lahir, riwayat persalinan, dan data status gizi TB/U. Pengumpulan data dilakukan melalui pengukuran tinggi badan, dan wawancara dengan kuisioner. Analisis data menggunakan uji korelasi spearman $(\alpha=0,05)$.

Hasil penelitian menunjukkan bahwa prevalensi stunting balita di Desa Ujung Piring Tahun 2016 sebesar 29\%, sebagian besar responden memiliki pendapatan di bawah upah minimum Kabupaten Bangkalan, sebagian besar balita memiliki berat lahir normal, sebagian besar balita memiliki panjang lahir normal. Analisis uji statistik menunjukkan terdapat hubungan antara pendapatan keluarga, berat lahir balita, dan panjang lahir balita dengan kejadian stunting di Desa Ujung Piring, Bangkalan.

Kesimpulan penelitian ini adalah faktor yang berhubungan dengan kejadian stunting balita usia 25-59 bulan di Desa Ujung Piring, Bangkalan adalah pendapatan keluarga, berat lahir balita, dan panjang lahir balita. Disarankan agar dinas kesehatan bekerja sama lintas sektor untuk dapat meningkatkan pendapatan masyarakat Desa Ujung Piring melalui pengoptimalan sektor pertanian serta kelautan di desa tersebut. Serta untuk pihak dinas kesehatan dan puskesmas agar dapat mengevaluasi serta meningkatkan program asupan gizi 1000 HPK sejak konsepsi, saat hamil dan usia 2 tahun pertama balita untuk dapat menurunkan prevalensi stunting.
\end{abstract}

Kata Kunci: Stunting Balita, Pendapatan Keluarga, Berat Lahir, Panjang Lahir

\section{ABSTRACT}

Stunting is still be nutritional problems in Indonesia. The prevalence of stunting of under five children in Bangkalan 2015 is highest in East Java. Many factors affect incidence of stunting among children under five. One of them is in the family characteristics and the characteristics of a toddler. The purpose of this study was to analyze the correlation between family income, birth weight and birth length with the incidence of stuntingin children.

This study was an observational study with cross sectional design. The population as many as 73 toddlers. Samples size of 62 toddlers were selected by simple random sampling 
method. Sample criteria was a toddler comes from a family of permanent residents, not had physical disability and mental disorders. The study variables are mother'seducation, father's occupation, mother employment status, household income, household size, age, birth weight, birth length, birth history, and nutritional status data H/A. Data collected through the measurement of height, and interviews with questionnaires. Data analysis using Spearman correlation test $(\alpha=0.05)$.

The results showed that the prevalence of stuntingchildren aged 25-59 months in Ujung Piring 2016 by 29\%, majority of respondents had an income below the minimum wage Bangkalan, most toddlers have a normal birth weight, most toddlers have a normal birth length. Analysis of statistical test showed there was a correlation between family income, birth weight infants, and birth length infants with incident of stunting in the village of Ujung Plates, Bangkalan.

The conclution of this study is factors that have correlationwith incidence of stuntingin children aged 25-59 months in Ujung Piring village Bangkalan is family income, birth weight infants and birth length of infants.It is recommended that health authorities work together with others sectors in order to increase people's income through optimization of agricultural and marine sector in the village. To health department and health centers in order to evaluate and improve the nutritional intake of 1000 HPK program since its conception, during pregnancy and the first 2 years toddler to be able to reduce the prevalence of stunting.

Key Words: Stunting Of Children, Birth Weight, Birth Length

\section{PENDAHULUAN}

Stunting merupakan Penilaian Status Gizi berdasarkan indikator panjang badan dibanding umur $(\mathrm{PB} / \mathrm{U})$ atau tinggi badan dibanding umur $(\mathrm{TB} / \mathrm{U})$ dimana hasil pengukuran antropometri menunjukkan ZScore <-2 SD sampai dengan -3 SD (pendek) dan <-3 SD (sangat pendek) (Kemenkes R.I,2012). Stunting digunakan sebagai indikator malnutrisi kronik yang menggambarkan riwayat kurang gizi anak dalam jangka waktu lama sehingga stunting menunjukkan bagaimana keadaan gizi sebelumnya (Kartikawati, 2011). Anak yang mengalami stunting dapat berdampakpada produktivitas mereka di masa dewasa. Penelitian membuktikan bahwa kemampuan membaca pada anak yang pendek lebih rendah dibandingkan pada anak yang normal (Gibney, 2009).

Banyak faktor yang mempengaruhi status gizi anak, baik faktor langsung maupun faktor tidak langsung, serta akar masalah. Akar masalah tersebut yaitu status ekonomi yang memberikan dampak buruk terhadap status gizi anak (Semba dan Bloem, 2001). Status gizi TB/U memberikan indikasi masalah gizi yang bersifat kronis sebagai akibat dari kemiskinan, pola pemberian makan yang kurang, perilaku hidup sehat sejak anak dilahirkan hingga berakibat anak menjadi pendek. Karakteristik keluarga yaitu pendapatan keluarga berhubungan dengan kejadian stunting pada balita usia 6-12 bulan (Astari, et al., 2005). 
Faktor risiko lain terhadap kejadian stunting yaitu berat lahir yang rendah. Hasil penelitian Paudel, et al di Nepal (2012) menunjukkan bahwa berat lahir rendah merupakan faktor risiko stunting, balita dengan berat lahir rendah memiliki risiko mengalami stunting 4,47 kali lebih besar daripada balita dengan berat lahir normal. Selain faktor berat lahir, panjang lahir merupakan faktor risiko lain dari stunting. Penelitian Meilyasari dan Isnawati (2014) menunjukkan bahwa panjang badan lahir merupakan faktor risiko terjadinya stunting yaitu 16,43 kali lebih besar daripada balita dengan panjang badan lahir normal

Data Pemantauan Status Gizi (PSG) Provinsi Jawa Timur Tahun 2015 menunjukkan bahwa prevalensi stunting balita di Jawa Timur sebesar 27,1\% terdiri dari $17,6 \%$ pendek dan $9,5 \%$ sangat pendek. Prevalensi stunting balita di Bangkalan paling tinggi di Jawa Timur yaitu sebesar 53,2\% dengan rincian prevalensi balita sangat pendek sebesar $27,4 \%$ dan balita pendek sebesar 25,8\% (PSG Jatim, 2015).

Berdasarkan data Puskesmas Bangkalan tahun 2015, Desa Ujung Piring merupakan desa yang memiliki prevalensi balita stunting paling tinggi di Kecamatan Bangkalan yaitu sebesar 50,2\%.Oleh karena itu penelitian ini bertujuan untuk menganalisis hubungan pendapatan keluarga, berat badan lahir balita, dan panjang badan lahir balita dengan kejadian stunting balita di Desa Ujung Piring, Bangkalan.

\section{METODE PENELITIAN}

Penelitian ini merupakan penelitian observasional dengan rancang bangun cross sectional. Penelitian dilakukan di Desa Ujung Piring, Kecamatan Bangkalan. Sampel penelitian adalah balita yang berusia 24-59 bulan yang memenuhi kriteria: balita berasal dari keluarga penduduk tetap, balita tidak mengalami cacat fisik dan gangguan mental. Besar sampel 62 balita yang dipilih dengan teknik simple random sampling.

Penentuan rumus besar besar sampel dilakukan dengan rumus:

$$
\begin{aligned}
& \mathrm{n}=\frac{z_{1-\frac{\alpha}{2}}^{2} \mathrm{P}(1-\mathrm{P}) \mathrm{N}}{d^{2}(N-1)+z_{1-\frac{\alpha}{2}}^{2} \mathrm{P}(1-\mathrm{P})} \\
& =\frac{1,96^{2} \times 0,5(1-0,5) \times 73}{0,05^{2} \times(73-1)+1,96^{2} \times 0,5(1-0,5)} \\
& =\frac{70,1092}{1,1404} \\
& =61,47 \\
& \mathrm{n}=62 \text { balita }
\end{aligned}
$$

Keterangan:

$\mathrm{n}=$ Besar Sampel balita

$\mathrm{N}=$ Besar populasi balita

$z_{1-\frac{\alpha}{2}}^{2}=$ Tingkat kemaknaan pada $\alpha=5 \%(\mathrm{Z}$ score $=1,96)$ 
$\mathrm{P}=$ Estimasi maksmimal 0,5 (Neldawati, 2006)

$\mathrm{d}=$ Sampling eror $(5 \%)$

Data yang dikumpulkan meliputi : karakteristik keluarga (pendidikan ibu, status pekerjaan ibu, pendapatan keluarga, jumlah anggota keluarga), dan karakteristik balita (umur, jenis kelamin, berat badan lahir, panjang badan lahir, dan riwayat persalinan).

Pengumpulan data dilakukan melalui wawancara yang mengacu pada kuesioner. Penilaian Stunting balita diukur secara antropometri dengan indeks tinggi badan/umur (TB/U). Data tinggi badan balita diperoleh melalui pengukuran tinggi badan menggunakan microtoise.

\section{HASIL DAN PEMBAHASAN}

\section{Karakateristik Keluarga Balita}

Karakteristik keluarga memiliki peran dalam pola pengasuhan balita, dimana pola pengasuhan ini berpengaruh terhadap pertumbuhan dan perkembangan balita. Karakteristik keluarga dalam penelitian ini dapat dilihat pada tabel 1 .

Tabel 1.Karakteristik Keluarga Balita Desa Ujung Piring Kecamatan Bangkalan

\begin{tabular}{lrr}
\hline \multicolumn{1}{c}{ Karakteristik } & n & \% \\
\hline Pendidikan Ibu & & \\
Rendah & 46 & 74,2 \\
Menengah & 10 & 16,1 \\
Tinggi & 6 & 9,7 \\
Status Pekerjaan Ibu & & \\
$\quad$ Bekerja & 13 & 21,0 \\
Tidak Bekerja & 49 & 79,0
\end{tabular}

\begin{tabular}{|c|c|c|}
\hline Karakteristik & $\mathbf{n}$ & $\%$ \\
\hline \multicolumn{3}{|l|}{ Pendapatan Keluarga } \\
\hline$<1.414 .000$ & 34 & 54,8 \\
\hline$\geq 1.414 .000$ & 28 & 45,2 \\
\hline $\begin{array}{c}\text { Jumlah } \\
\text { Keluarga }\end{array}$ & & \\
\hline Besar ( $\geq 4$ orang) & 27 & 43,5 \\
\hline Kecil ( $\leq 4$ orang) & 35 & 56,5 \\
\hline \multicolumn{3}{|l|}{ Pengeluaran Pangan } \\
\hline $\begin{array}{l}\text { Kuartil 1 } \\
600.000)\end{array}$ & 23 & 37,1 \\
\hline $\begin{array}{l}\text { Kuartil } 2 \text { (601.000- } \\
900.000)\end{array}$ & 15 & 24,2 \\
\hline $\begin{array}{l}\text { Kuartil } 3(901.000- \\
1.500 .000)\end{array}$ & 21 & 33,9 \\
\hline $\begin{array}{l}\text { Kuartil 4(1.501.000- } \\
3.000 .000)\end{array}$ & 3 & 4,8 \\
\hline
\end{tabular}

Tabel 1 menunjukkan bahwa sebagian besar tingkat pendidikan ibu tergolong rendah (tamat SD) yaitu $74,6 \%$. Tingkat pendidikan ibu yang lebih tinggi memiliki hubungan terhadap pengasuhan yang baik pada anak, seperti: penggunaan garam beryodium, pemberian kapsul vitamin A, imunisasi yang lengkap dan sanitasi yang baik (Supriyanti, 2014). Penelitian Ramli et al di Maluku (2009) menemukan bahwa pendidikan ibu berhubungan signifikan dengan kejadian stunting pada balita. Hal ini dapat disebabkan karena peran pengasuhan lebih besar pada ibu daripada ayah. Ayah lebih banyak bekerja sehingga waktu yang dihabiskan dengan anak lebih sedikit (Ni'mah, 2015). Penelitian di Nepal oleh Tiwari, et al (2014) menunjukkan hal yang sama bahwa pendidikan ibu berhubungan dengan kejadian stunting balita. 
Rendahnya pendidikan ibu merupakan penyebab utama dari kejadian stunting pada anak sekolah dan remaja di Nigeria. Ibu yang berpendidikan lebih tingg lebih memungkinkan untuk membuat keputusan yang akan meningkatkan gizi dan kesehatan anak-anaknya. Tingkat pendidikan ibu juga menentukan kemudahan ibu dalam menyerap dan memahami pengetahuan gizi yang diperoleh. Hal ini bisa dijadikan landasan untuk membedakan metode penyuluhan yang tepat. Dari kepentingan gizi keluarga, pendidikan diperlukan agar seseorang terutama ibu lebih tanggap terhadap adanya masalah gizi di dalam keluarga dan bisa mengambil tindakan secepatnya (Suhardjo, 2003).

Sebagian besar ibu balita dalam penelitian ini berstatus tidak bekerja (ibu rumah tangga) yaitu sebesar 79\%. Hasil penelitiann Diana (2006) mengemukakan bahwa ada hubungan bermakna antara pola asuh makan dengan pekerjaan ibu. Ibu yang bekerja di luar rumah dapat menyebabkan anak kurang terawat, selain itu ibu yang bekerja di luar rumah cenderung memiliki lebih sedikit waktu untuk melaksanakan tugas rumah tangga dibanding ibu yang tidak bekerja, oleh karena itu pola pengasuhan anak akan terpengaruh.

Ibu yang berperan sebagai ibu rumah tangga biasanya memiliki pola asuh terhadap tumbuh kembang balita yang lebih baik daripada ibu yang memiliki pekerjaan di luar rumah, ibu dapat lebih fokus mengasuh anak (Septiana, dkk 2010).

Sebagian besar $(54,8 \%)$ pendapatan keluarga balita berada di bawah upah minimum kabupaten Bangkalan yaitu kurang dari 1.414.000. Pendapatan merupakan salah satu indikator yang menentukan status ekonomi. Hasil penelitian di Nepal menunjukkan bahwa indeks kekayaan rumah tangga merupakan faktor risiko stunting (Tiwari, dkk 2014). Skor indeks kesejahteraan rumah tangga yang lebih tinggi berhubungan signifikan dengan peningkatan proteksi kejadian stunting (Gewa dan Nannette, 2012).

Sebagian besar tipe keluarga balita merupakan keluarga kecil (terdiri dari $\leq 4$ orang) yaitu sebesar $56,6 \%$. Jumlah anggota keluarga berpengaruh terhadap penyediaan dan distribusi pangan dalam keluarga. Pada rumah tangga yang memiliki jumlah anggota keluarga relatif banyak kualitas konsumsi pangan akan semakin buruk (Ariningsih dan Rahman, 2008). Keluarga dengan keadaan sosial ekonomi yang kurang dengan jumlah anak yang banyak akan mengakibatkan kebutuhan primer seperti makanan, sandang dan perumahan tidak terpenuhi (Soetjiningsih, 1995). 
Penelitian Fikadu et al, (2014) di Euthopia Selatan menunjukkan bahwa balita yang tinggal dengan 5 sampai 7 anggota keluarga memiliki risiko 2,97 kali lebih besar mengalami stunting daripada balita yang tinggal dengan 2 sampai 4 anggota keluarga. Hal ini disebabkan oleh kurangnya ketersediaan pangan jika banyak orang yang tinggal dalam satu rumah.

Pengeluaran pangan responden paling banyak berada pada kuartil 1 (300.000-600.000) yaitu sebesar 37,1\%. Hasil penelitian Nasikhah (2012) menunjukkan bahwa tingkat pendapatan perkapita yang ditunjukkan dalam pengeluaran untuk belanja merupakan faktor risiko kejadian stunting pada balita di Semarang Timur dengan OR sebesar 7,21. Penelitian senada juga menyebutkan bahwa pengeluaran pangan keluarga yang rendah memiliki risiko 6,353 kali lebih besar mengalami stunting daripada keluarga dengan pengeluaran tinggi (Annisa, 2012).

Menurut Arifin (2004), semakin besar pengeluaran pangan dalam rumah tangga menunjukkan semakin rendahnya ketahanan pangan rumah tangga tersebut. Hal tersebut dikaitkan dengan kemampuan dalam mengakses pangan. Menurut Berg (2010), dengan bertambahnya pengeluaran untuk konsumsi tidak selalu diikuti dengan perbaikan pola konsumsi pangan.
Meskipun seseorang cenderung menghabiskan sebagian besar pendapatannya untuk konsumsi belum tentu mencermikan bahwa apa yang dimakan tersebut sudah baik dalam mutu gizinya. Selain itu, kemampuan keluarga dalam membeli makanan tidak hanya dipengaruhi oleh besarnya pendapatan tetapi harga bahan makanan. Beberapa harga bahan makanan yang mahal cenderung tidak dipilih dan dibeli, jadi dalam keluarga jenis makanan tersebut jarang disajikan sehingga dalam memenuhi kebutuhan gizi masih kurang.

\section{Karakteristik Balita}

Karakteristik balita merupakan hal-hal yang melekat dalam diri balita. Karakteristik balita dapat dilihat pada tabel 2 berikut.

Tabel 2. Karakteristik Balita di Desa Ujung Piring, Kecamatan

\begin{tabular}{lrl}
\hline \multicolumn{1}{c}{ Karakteristik } & n & \% \\
\hline Umur & 31 & 50,0 \\
24-35 bulan & 16 & 25,8 \\
36-47 bulan & 15 & 24,2 \\
$48-59$ bulan & & \\
Jenis Kelamin & 28 & 45,2 \\
$\quad$ Laki-laki & 34 & 54,8 \\
$\quad$ Perempuan & & \\
Berat Badan Lahir & 4 & 6,5 \\
$\quad$ BBLR (<2500 gr) & 58 & 93,5 \\
$\begin{array}{l}\text { BB lahir normal } \\
\text { ( } \geq 2500 \text { gr) }\end{array}$ & & \\
Panjang lahir & & \\
PB lahir pendek $(<48$ & 6 & 9,7 \\
cm) & & \\
PB lahir normal $(\geq 48$ & 56 & 90,3 \\
cm) & &
\end{tabular}




\begin{tabular}{llll}
\hline \multicolumn{1}{c}{ Karakteristik } & n & \% \\
\hline $\begin{array}{l}\text { Usia Kehamilan } \\
\text { Kurang bulan } \\
\text { minggu) }\end{array}$ & $(<37$ & 4 & 6,5 \\
$\begin{array}{l}\text { Cukup bulan } \quad(\geq 37 \\
\text { minggu) }\end{array}$ & 58 & 93,5 \\
$\begin{array}{l}\text { Status Gizi TB/U } \\
\quad \text { Stunting (pendek dan }\end{array}$ & 18 & 29,0 \\
$\quad \begin{array}{l}\text { sangat pendek) } \\
\text { Non stunting }\end{array}$ & 44 & 71,0 \\
\hline
\end{tabular}

Separuh balita berusia antara 24 sampai 35 bulan. Usia merupakan salah satu faktor internal anak yang mempengaruhi kejadian stunting. Gangguan pertumbuhan pada tinggi badan berlangsung pada kurun waktu yang cukup lama, dari beberapa bulan sampai beberapa tahun. Oleh karena itu indikator $\mathrm{TB} / \mathrm{U}$ memberikan indikasi adanya masalah gizi yang kronis (Soegianto, et all., 2007). Semakin meningkatnya kejadian stunting seiring dengan meninngkatnya usia pada balita dapat dipengaruhi oleh asupan nutrisi balita. Pada usia yang semakin meningkat, konsumsi ASI akan digantikan dengan makanan padat. Di sisi lain frekuensi dan kualitas makan disamakan dengan jenis dan frekuensi makan orang dewasa dalam keluarga, dan anak sudah mulai bermain di luar rumah sehingga risiko terkena penyakit infeksi lebih besar (Adeba, et all, 2014). Kejadian stunting merupakan kejadian yang sulit diperbaiki karena gangguan pertumbuhan akan bertahan sampai 2 aatau 3 tahun ke depan (Ramli, et all, 2009). Sampai usia 2 tahun pertambahan tinggi badan berlangsung cepat setelah itu pertumbuhan berlangsung stabil di bawah pengaruh hormon pertumbuhan sampai pubertas (Narendra, 2002). Di akhir tahun pertama panjang badan bertambah kurang lebih 50\% dibanding saat lahir. Pada usia dua tahun, pertumbuhan bertambah kurang lebih 75\% dibandingh saat lahir disertai badan yang mengurus. Potensi untuk tumbuh tergantung pada sifat dan pola tumbuh kembang, namun hal lain yang sangat mempengaruhi adalah asupan dan penyerapan zat gizi, pelayanan kesehatan dasar, dan lingkungan serta upaya peningkatan derajat kesehatan (Siswanto, 2010). Pertumbuhan pada usia balita dan pra sekolah lebih lambat dibandingkan pada masa bayi, namun pertumbuhannya stabil. Melambatnya kecepatan pertumbuhan ini tercermin dalam penurunan nafsu makan, padahal dalam masa ini anak-anak membutuhkan kalori dan zat gizi yang adekuat untuk memenuhi kebutuhan zat gizi mereka (Brown, 2005).

Hasil penelitian Ramli dkk (2009) di Maluku Utara menunjukkan bahwa prevalensi stunting pada anak usia 25-59 bulan lebih tinggi dibandingkan anak usia 0-23 bulan. Hasil tersebut mirip dengan hasil dari penelitian di Bangladesh, India, dan Pakistan dimana anak-anak berusia 24-59 bulan memiliki risiko lebih besar mengalami pertumbuhan yang terhambat (Annisa, 2012).Penelitian lain menyatakan anak-anak Sudan yang berusia 6-72 bulan yang berada dalam kondisi stunting, pada anak-anak yang berusia 1-2 tahun lebih 
mungkin untuk pulih dari stunting dari pada anak-anak yang berusia lebih dari 2 tahun (Sedgh et al, 2000).

Sebagian besar balita $(54,8 \%)$ berjenis kelamin perempuan. Penelitian di Ghana menunjukkan bahwa stunting lebih banyak ditemukan pada anak perempuan dibandingkan laki-laki (Eunice dan Sarah, 2013). Namun dalam penelitian Taguri dkk (2008) di Libya menunjukkan bahwa prevalensi stunting pada anak laki-laki lebih besar dibanding anak perempuan.

Sebagian besar balita memiliki berat badan dan panjang badan lahir normal yaitu masing-masing 93,5 \% dan 90,3\%. Hasil penelitian Taguri dkk (2009), di Libya menunjukkan bahwa berat lahir rendah merupakan salah satu faktor risiko stunting. Hasil penelitian Ernawati dkk (2013), di Bogor menunjukkan bahwa ada perbedaan signifikan antara kelompok bayi yang memiliki panjang badan lahir normal dan kelompok bayi yang memiliki panjang badan lahir pendek dengan kejadian stunting.

Sebesar 29\% balita di Desa Ujung Piring mengalami stunting. Angka ini menunjukkan bahwa prevalensi stunting balita di Desa Ujung Piring lebih tinggi dibandingkan prevalensi stunting Jawa Timur yang sebesar 27,1\%.

\section{Hubungan Pendapatan Keluarga dengan Kejadian Stunting}

Berdasarkan distribusi silang pada tabel 3 diketahui bahwa proporsi balita stunting lebih banyak terdapat pada keluarga dengan pendapatan rendah yaitu sebesar $38,2 \%$, sedangkan pada keluarga dengan pendapatan tinggi terdapat $17,9 \%$ balita stunting.

Tabel 3. Distribusi Silang Antara Pendapatan Keluarga dengan Kejadian Stunting Balita di Desa Ujung Piring 2016

\begin{tabular}{lllrrrrc}
\hline \multirow{2}{*}{ Pendapatan Keluarga } & \multicolumn{2}{c}{ Stunting } & \multicolumn{2}{c}{ Non Stunting } & \multicolumn{2}{c}{ Total } \\
\cline { 2 - 8 } & \multicolumn{2}{c}{$\mathrm{n}$} & $\%$ & $\mathrm{n}$ & $\%$ & $\mathrm{n}$ & $\%$ \\
\hline Rendah $(<1.414 .000)$ & 13 & 38,2 & 21 & 61,8 & 34 & 100,0 \\
Tinggi & 5 & 17,9 & 23 & 82,1 & 28 & 100,0
\end{tabular}

Tabel 4. Distribusi Silang Antara Berat Lahir dengan Kejadian Stunting Balita di Desa Ujung Piring 2016

\begin{tabular}{lllrrrrr}
\hline \multirow{2}{*}{ Berat Lahir } & \multicolumn{2}{c}{ Stunting } & \multicolumn{2}{c}{ Non Stunting } & \multicolumn{2}{c}{ Total } \\
\cline { 2 - 8 } & \multicolumn{2}{c}{$\mathrm{n}$} & $\%$ & $\mathrm{n}$ & $\%$ & $\mathrm{n}$ & $\%$ \\
\hline BB Lahir Rendah & 3 & 75,0 & 1 & 25,0 & 4 & 100,0 \\
BB Lahir Normal & 15 & 25,9 & 43 & 74,1 & 58 & 100,0
\end{tabular}

Tabel 5. Distribusi Silang Antara Berat Lahir dengan Kejadian Stunting Balita di Desa Ujung Piring 2016

\begin{tabular}{lllrrrrr}
\hline \multirow{2}{*}{ Panjang Lahir } & \multicolumn{2}{c}{ Stunting } & \multicolumn{2}{c}{ Non Stunting } & \multicolumn{2}{c}{ Total } \\
\cline { 2 - 8 } & \multicolumn{2}{c}{$\mathrm{n}$} & $\%$ & $\mathrm{n}$ & $\%$ & $\mathrm{n}$ & $\%$ \\
\hline PB Lahir Rendah & 3 & 50,0 & 3 & 50,0 & 6 & 100,0 \\
PB Lahir Normal & 15 & 26,8 & 41 & 73,2 & 56 & 100,0
\end{tabular}


Hasil analisis uji korelasi spearman menunjukkan nilai $\mathrm{p}$ sebesar $0,08 \quad(\mathrm{p}<\alpha=0,05)$ artinya ada hubungan antara pendapatan keluarga dengan kejadian stunting balita di Desa Ujung Piring. Hasil penelitian ini sesuai dengan penelitian yang dilakukan oleh Candra (2011) di Semarang yang menyatakan bahwa tingkat pendapatan yang rendah merupakan faktor risiko kejadian stunting, dimana keluarga dengan pendapatan rendah memiliki risiko 2,3 kali lebih besar memiliki anak stunting dibanding keluarga dengan pendapatan cukup. Hasil penelitian di Maluku Utara (Ramli, et al., 2009), dan di Nepal (Taguri, et al., 2004) menyebutkan hasil yang sama pula bahwa pendapatan yang rendah berhubungan dengan kejadian stunting pada balita.

Menurut Adriani (2012) daya beli keluarga untuk makanan bergizi dipengaruhi oleh pendapatan keluarga karena dalam menentukan jenis pangan yang akan dibeli tergantung pada tinggi rendahnya pendapatan. Daya beli pangan rumah tangga mengikuti tingkat pendapatan keluarga. Dengan pendapatan yang tinggi dapat dimungkinkan terpenuhinya kebutuhan makanan seluruh anggota keluarga. Namun sebaliknya tingkat pendapatan keluarga yang rendah mengakibatkan rendahnya daya beli pangan rumah tangga. Daya beli terhadap bahan pangan yang rendah menyebabkan kurang terpenuhinya kebutuhan zat gizi balita (Ranoor, 2010).

Masyarakat yang berpenghasilan rendah biasanya membelanjakan sebagian besar dari pendapatan untuk membeli makanan. Pendapatan juga menentukan jenis pangan yang akan dikonsumsi. Di negara yang berpendapatan rendah mayoritas pengeluaran pangan digunakan untuk membeli serealia, sedangkan di negara yang memiliki pendapatan per kapita tinggi pengeluaran untuk membeli bahan pangan protein meningkat (Annisa, 2012). Status ekonomi rumah tangga dinilai memiliki dampak yang signifikan terhadap kemungkinan anak menjadi pendek. WHO merekomendasikan stunting sebagai alat ukur atas tingkat sosial ekonomi yang rendah (Zere dan McIntyre, 2003).

\section{Hubungan Berat Lahir Balita dengan Kejadian Stunting}

Berdasarkan hasil distribusi silang pada tabel 4, diketahui bahwa proporsi balita stunting lebih banyak terdapat pada balita dengan berat badan lahir rendah yaitu sebesar $75 \%$, sedangkan pada balita dengan berat badan lahir normal terdapat $25,9 \%$ balita yang mengalami stunting. Hasil analisis uji korelasi spearman menunjukkan nilai $\mathrm{p}$ sebesar 0,043 $(\mathrm{p}<\alpha=0,05)$ artinya ada hubungan antara 
berat badan lahir dengan kejadian stunting balita. Hasil ini sesuai dengan hasil pennelitian Paudel et al (2012) d Nepal yang menunjukkan bahwa berat lahir yang rendah merupakan faktor risiko kejadian stunting. Balita dengan berat lahir rendah berisiko 4,47 kali mengalami stunting daripada balita dengan berat lahir normal. Penelitian serupa oleh Kolbrek (2011) di Medan juga menunjukkan hasil yang sama, bahwa balita yang memiliki riwayat berat lahir rendah memiliki risiko 5,8 kali lebih besar mengalami stunting daripada balita dengan riwayat berat lahir normal.

Berat badan merupakan salah satu indikator kesehatan bayi baru lahir. Berat badan lahir merupakan parameter yang umum dipakai untuk mengambarkan pertumbuhan janin pada masa kehamilan. Bayi dengan berat badan lahir rendah akan lebih rentan terhadap pengaruh lingkungan yang kurang baik di masa mendatang. Anak yang dilahirkan dengan berat badan rendah memiliki risiko lebih besar mengalami malnutrisi. Pertumbuhan dan perkembangan akan lebih lambat yang ditandai pertambahan berat badan dan tinggi badan yang kurang optimal. Berat lahir rendah juga akan menghasilkan generasi yang rentan terhadap penyakit infeksi.

Berat lahir sangat berkaitan dengan kematian janin, neonatal, dan postneonatal, morbiditas bayi dan anak, serta pertumbuhan dan perkembangan jangka panjang. Berat badan lahir berbanding terbalik dengan risiko terjadinya penyakit hipertensi, penyakit kardiovaskular dan diabetes tipe 2 pada masa dewasa. Berat badan lahir yang rendah, maupun pertambahan berat badan pasca lahir yang terlalu cepat (makanan pendamping ASI dini), atau kombinasi keduanya merupakan faktor predisposisi penyakit tersebut (Kharma, et al., 2007).

Di negara berkembang bayi dengan berat lahir rendah (BBLR) lebih cenderung mengalami retardasi pertumbuhan intrauteri yang terjadi karena buruknya gizi ibu dan meningkatnya angka infeksi dibandingkan dengan negara maju. (Gibney, 2008). Anak yuang BBLR ke depannya akan memiliki ukuran antropometri tubuh yang kurang di masa dewasa. Bagi perempuan yang lahir dengan berat rendah, memiliki risiko besar untuk menjadi ibu yang stunted sehingga akan cenderung melahirkan bayi dengan berat lahir rendah seperti dirinya. Bayi yang dilahirkan oleh ibu yang stunted tersebut akan menjadi perempuan dewasa yang stunted juga, dan akan membentuk siklus yang sama seperti sebelumnya. (Semba, dan Bloem 2001). 
Hubungan Berat Lahir Balita dengan Kejadian Stunting

Berdasarkan hasil distribusi silang pada tabel 5, diketahui bahwa proporsi balita stunting lebih banyak terdapat pada balita dengan panjang badan lahir rendah yaitu sebesar $50 \%$, sedangkan pada balita dengan panjang badan lahir normal terdapat $26,8 \%$ balita yang mengalami stunting.

Hasil analisis uji korelasi spearman menunjukkan nilai $\mathrm{p}$ sebesar $0,08(\mathrm{p}<\alpha=0,05)$ artinya ada hubungan antara panjang badan lahir dengan kejadian stunting balita. Hasil ini sesuai dengan penelitian Ni'mah (2015) yang menyatakan bahwa ada hubungan bermakna antara panjang badan lahir dengan kejadian stunting balita. Balita dengan panjang badan lahir kurang berisiko mengalami stunting 4,091 kali lebih besar daripada balita yang memiliki riwayat panjang badan lahir normal.

Hasil penelitian serupa juga disebutkan oleh Meilyasari dan Isnawati (2014) di Kendal bahwa panjang badan lahir rendah merupakan faktor risiko terjadinya stunting 16,43 kali lebih besar daripada balita dengan panjang badan lahir normal.

Risiko untuk mengalami gangguan tumbuh (growth faltering) lebih besar pada bayi yang telah mengalami falter yaitu keadaan pada masa kehamilan dan prematuritas. Artinya panjang badan yang jauh di bawah rata-rata lahir disebabkan karena sudah mengalami retardasi pertumbuhan saat dalam kandungan (Kusharisupeni, 2004).

Penelitian di daerah Indramayu menyatakan bahwa rata-rata panjang badan bayi prematur berada di bawah persentil10. Pertumbuhan yang lambat pada bayi prematur dipengaruhi oleh retardasi linier yang terjadi sejak dalam kandungan selain karena singkatnya usia kehamilan. Bayi yang mengalami gangguan tumbuh (growth faltering) sejak usia dini menunjukkan risiko untuk mengalami growth faltering pada periode umur berikutnya. Stunting yanng disebabkan oleh growth faltering dan catch up growth yang tidak memadai, mencerminkan ketidakmampuan untuk mencapai pertumbuhan optimal. Tetapi jika diberikan asupan gizi yang adekuat maka pola pertumbuhan normal dapat terkejar (catch up) Panjang badan lahir bersamaan dengan berat badan lahir merupakan indikator yang digunakan untuk melihat keadaan kesehatan janin dalam kandungan.

\section{KESIMPULAN DAN SARAN}

Faktor yang berhubungan dengan kejadian stunting balita di Desa Ujung Piring yaitu 
pendapatan keluarga, berat badan lahir, dan panjang badan lahir balita.

Disarankan agar dinas kesehatan bekerja sama lintas sektor untuk dapat meningkatkan pendapatan masyarakat Desa Ujung Piring melalui pengoptimalan sektor pertanian serta kelautan di desa tersebut. Serta untuk pihak dinas kesehatan dan puskesmas agar dapat mengevaluasi serta meningkatkan program asupan gizi 1000 HPK sejak konsepsi, saat hamil dan usia 2 tahun pertama balita untuk dapat menurunkan prevalensi stunting.

\section{DAFTAR PUSTAKA}

Adeba, A.S., Garoma, H.F., Gemede, W. (2014). Prevalence of Stunting and Associated Factors of Children among 6-59 Months Age in Guto Gida District, Ethiopia. Food Science and Quality Management. Vol 29.

Adriani, M., dan Wirjatmadi, B. (2012). Pengantar Gizi Masyarakat. Jakarta: Kharisma Putra Utama.

Anisa, P., 2012. Faktor-faktor yang berhubungan dengan Kejadian Stunting Pada Balita Usia 25-60 Bulan di Kelurahan Kalibaru Depok Tahun 2012. Skripsi. Jakarta: Universitas Indonesia.

Anugraheni, H.S. 2012. "Faktor Risiko Kejadian Stunting pada Anak Usia 1236 Bulan di Kecamatan Pati, Kabupaten Pati”. Diakses pada 6 Juni 2016 dari www.pustaka.unpad.ac.id

Ariningsih, E., Rachman, H.P.S. (2008). Strategi Peningkatan Ketahanan Pangan Rumah Tangga Rawan Pangan. Analisis Kebijakan Pertanian Vol 6. Hal 239255.

Diakses

dari: http://pse.litbang.pertanian.go.id/ind/pdf files/ART6-3c.pdf.

Brown, J.E. 2005. Nutrition Through the Life Cycle (2nd Edition). USA: Wadsworth.

Chandra, A. (2013). Hubungan Underlyng Factors dengan Kejadian Stunting pada Anak 1-2 Tahun. Journal of Nutrition and Health. Vol 1. No 1.

Dinas Kesehatan Provinsi Jawa Timur. (2015). Pemantauan Status Gizi. Surabaya.

Ernawati, F., Rosmalina, Y., Permanasari, Y. (2013). Pengaruh Asupan Protein Ibu Hamil dan Panjang Badan Bayi Lahir terhadap Kejadian Stunting pada Anak Usia 12 Bulan di Kabupaten Bogor. Jurnal Penelitian Gizi dan Makanan Vol. 36 (1): 1-11. Diakses dari: http://ejournal.litbang.depkes.go.id/inde x.php/pgm/article/view/3388.

Eunice, A and D. Sarah, 2013. An Assesment of Nutritional Status of Under Five Children in Four District in The Central Region of Ghana. Asian Journal of Agriculture and Rural Development, Vol 3. Page. 851860.

Fikadu, T.S., Assegid dan L. Dube, (2014). Faktor Associated with Stunting Among Children of Age 24 to 59 Month in Meskan District, South Ethiopia. BMC Public Health. 14:800.

Gewa, C.A and Yandel,N. 2012. Undernutrition Among Kenyan Children: Contribution of Child, Maternal, and Household Factors. Public Health Nutrition, Vol.15 page. 29-38.

Gibney,M.J., 2009. Gizi Kesehatan Masyarakat. Jakarta: EGC.

Kartikawati, P.R.F., 2011. Faktor yang Mempengaruhi Kejadian Stunted Growth pada Anak Balita di Wilayah Kerja Puskesmas Arjasa Kabupaten Jember. Skripsi. Universitas Jember.

Kemenkes RI. (2012). Riset Kesehatan Dasar 2013. Jakarta: Badan Penelitian 
dan Pengembangan Kesehatan, Kementerian Kesehatan RI.

Kolbrek, M. (2011). Malnutrition and Associated Risk Factors in Children Aged 6-59 Months In Urban Indonesia. Master Thesis. Unversity of Oslo.

Kusharisupeni. 2004. Growth faltering pada bayi di Kabupaten Indramayu Jawa Barat. Makara Kesehatan.; 6:1-5

Meilyasari F, dan M.Isnawati. 2014. Faktor Risiko Kejadian Stunting Pada Balita Usia 12 Bulan Di Desa Purwokerto Kecamatan Patebon, Kabupaten Kendal. Journal of Nutrition College, Volume 3, Nomor 2. Diakses dari: http://download.portalgaruda.org/article. php?article.

Narendra, MB dkk.(2002). Tumbuh Kembang Anak dan Remaja. Jakarta: Sagung Seto.

Nasikhah, R. Dan Margawati, A. (2012). Faktor Risiko Kejadian Stunting Pada Balita Usia 24-36 Bulan di Kecamatan Semarang Timur. Journal of Nutrition College Vol.1 No 1.

Neldawati, 2006. Hubungan Pola Pemberian Makan pada Anak dan Karakteristik Lain dengan Status Gizi Balita 6-59 Bulan di Laboratoriun Gizi Masyarakat Puslitbang Gizi dan Makanan (P3GM) (Analisa Data Sekunder Data Balita Gizi Buruk Tahun 2005). Skripsi. Universitas Indonesia.

Ni'mah, Khoirun. (2015). Hubungan Faktor Karakteristik, Pola Konsumsi, dan Status Infeksi dengan Kejadian Stunting Balita. Skripsi. Surabaya: Universitas Airlangga.

Paudel R, Pradhan B., Wagle RR, Pahari DP, Onta SR. (2012). Risk Factors for Stunting Among Children in Nepal. Medical Journal Vol. 10 No 3: 18-24.

Ramli A.K.E., Inder, K.J., Bowe, S.J., Jacobs, J., dan Dibley, M.J. (2009).
Prevalence and Risk Factors for Stunting and Severe Stunting Among Under Fives in North Maluku Province of Indonesia. BMC Pediatric 9:64. Diakses dari: http://bmcpediatr.biomedcentral.com/a rticles/10.1186/1471-2431-9-64.

Ranoor, R.N.F. (2010). Hubungan Faktor Sosio-Ekonomi, Tingkat Konsumsi, Status Infeksi, dan Status Imunitas dengan Status Gizi Blaita. Skripsi. Surabaya: Universitas Airlangga.

Semba, R.D dan M.W., Bloem. (2001). Nutrition and Health in Developing Countries. New Jersey: Humana Press.

Sedgh, Gilda. (2000). Dietary Vitamin A Intake and Non Dietary Factors Are Associated with Reversal of Stunting in Children. Journal of Nutrition 135 2520-2525.

Septiana, R., Djannah, R.S.N., Djamil, M.D. (2010). Hubungan Antara Pola Pemberian Makanan Pendamping ASI dan Status Gizi Balita Usia 6-24 Bulan di Wilayah Kerja Puskesmas Gedongtengen Yogyakarta. Jurnal Kesehatan Masyarakat Vol.4 No 2. Diakses dari: http://download.portalgaruda.org/articl e.php?article.

Siswanto, H. (2010). Pendidikan Kesehatan Anak Usia Dini. Yogyakarta: Pustaka Rihama.

Suhardjo. (2003). Berbagai Cara Pendidikan Gizi. Jakarta: Bumi Aksara.

Soetjiningsih. (1995). Tumbuh Kembang Anak. Jakarta: Penerbit Buku Kedokteran ECG.

Supriyanti, NT, 2014. Hubungan Antara Riwayat Pemberian ASI, Pola Konsumsi, dan Kejadian Infeksi dengan Status Gizi Balita Usia 12-59 Bulan di Desa Baban, Kecamatan Gapura, Sumenep. Skripsi. Universitas Airlangga. 
Taguri, A.I., Betilmal, S.M. Mahmud, A.M. Ahmed, O. Goulet, P. Galan, dan S. Hercberg. (2009). Risk Factors for Stunting Among Under Five in Libya. Public Health Nutrition, 12(8): 1141-1149. DOI: $10.1017 / \mathrm{S} 1368980008003716$

Diakses dari: http://www.ncbi.nlm.nih.gov/pubme d/18789172.

Tiwari, R., Ausman, L.M., dan Agho, K.E. (2014). Determinant of Stunting and severe Stunting Among Under Fives: Evidence from the 2011 Nepal Demographic and Health Survey. BMC Pediatric 2014 14:239 DOI: 10.1186. diakses dari: http://bmcpediatr.biomedcentral.com/a rticles/10.1186/1471-2431-14-239.

Zere, E dan McIntyre. 2003. Inequities In Under Five Child Malnutrition in South Africa. International Journal for Equity in Health. 